\title{
Anti-CCP antibodies and bone
}

\author{
Giovanni Orsolini, Ombretta Viapiana, Maurizio Rossini, Giovanni Adami, Cristian Caimmi, Angelo Fassio and \\ Davide Gatti
}

Dear Editor.

We read with great interest the paper of Cheng et al. [1]. They demonstrate for the first time as anti-cyclic citrullinated peptides antibodies (Anti-CCP) are an independent risk factor for fracture and this data is of high clinical relevance in stratifying rheumatoid arthritis (RA) patients. The authors have a wide population and were able to take into consideration a lot of factors involved in bone disease related and unrelated to RA. They did confirm our previous reports of a negative effect of Anti-CCP on BMD [2], and also showed a relation with FRAX 10 year calculated fracture risk. In particular, the BMD difference was observed at femoral neck, site of cortical bone that is the same of periarticular bone were erosions occur $[3,4]$. Nevertheless, the Authors failed to find any correlation between Anti-CCP titer and BMD. This last data is in contrast with other previous clinical reports of a titer dependent effect of Anti-CCP on bone [2,5].

The reasons of these discrepancies are not straightforward. A possible explanation of lack of correlation between Anti-CCP titer and BMD could be the use of BMD as $\mathrm{g} / \mathrm{cm}^{2}$ and not as Z-score in the analysis. Z-score has the advantage to evaluate better the bone loss correcting for age and gender. Another possible confounder is the evaluation of glucocorticoids (GCs) as a dichotomous variable. It is not clear how the patients were considered "users" and there were no data on mean dose or duration of use, thus of a cumulative dose. The Authors report also data on anti-osteoporosis medications, but they are unspecified, even if they probably refer to antiresorptive drugs. Moreover, data on vitamin D and calcium, either supplements and serum levels, are completely lacking. Vitamin D and PTH are key determinants of cortical bone (e.g. femoral neck) mass [3], so their inclusion in the analysis would have been of critical importance.

We think the paper is of great interest but that some of the variables taken into consideration should be implemented and that a more complex statistical analysis is needed to take the best from its data.

\section{Abbreviations}

Anti-CCP: anti cyclic citrulline peptides antibodies; BMD: bone mineral density; GCs: glucocorticoids; PTH: parathormone

\section{Acknowledgements}

Not applicable.

Funding

Not applicable.

\section{Availability of data and materials \\ Non applicable.}

\section{Authors' contributions}

All the authors listed gave contribution for the paper. All authors read and approved the final manuscript.

\section{Ethics approval and consent to participate Not applicable.}

\section{Consent for publication}

The authors give consent to the publication.

\section{Competing interests}

The authors declare that they have no competing interests.

\section{Publisher's Note}

Springer Nature remains neutral with regard to jurisdictional claims in published maps and institutional affiliations.

Published online: 10 April 2018

\section{References}

1. Cheng TT, Yu SF, Su FM, Chen YC, Su BY, Chiu WC, et al. Anti-CCP-positive patients with RA have a higher 10-year probability of fracture evaluated by FRAX(R): a registry study of RA with osteoporosis/fracture. Arthritis Res Ther. 2018;20(1):16.

2. Orsolini G, Caimmi C, Viapiana O, Idolazzi L, Fracassi E, Gatti D, et al. Titer-Dependent Effect of Anti-Citrullinated Protein Antibodies On Systemic Bone Mass in Rheumatoid Arthritis Patients. Calcif Tissue Int. 2017;101(1):17-23.

3. Rossini M, Bagnato G, Frediani B, lagnocco A. L.A. Montagna G, Minisola G et al. Relationship of focal erosions, bone mineral density, and parathyroid hormone in rheumatoid arthritis. J Rheumatol. 2011;38(6):997-1002.

4. Rossini M, Adami G, Viapiana O, Idolazzi L, Orsolini G, Fassio A, et al. Osteoporosis: an Independent Determinant of Bone Erosions in Rheumatoid Arthritis? J Bone Miner Res. 2017;32(10):2142-3.

5. Bugatti S, Bogliolo L, Vitolo B, Manzo A, Montecucco C, Caporali R. Anti-citrullinated protein antibodies and high levels of rheumatoid factor are associated with systemic bone loss in patients with early untreated rheumatoid arthritis. Arthritis Res Ther. 2016;18(1):226.

* Correspondence: giovanniorsolini@gmail.com

Policlinico G.B. Rossi, Rheumatology Unit, Department of Medicine, Piazzale L. Scuro 10, 37134 Verona, Italy 